\title{
A Perspective on the Mobilization, Localization and Delivery of Molecules in the Crowded Bacterial Cytoplasm
}

\section{J. T. Trevors*}

Laboratory of Microbiology, School of Environmental Sciences, University of Guelph, 50 Stone Rd., East, Guelph, Ontario, N1G 2W1, Canada

\begin{abstract}
It has been assumed that diffusion of molecules in the bacterial cytoplasm is the mechanism that moves molecules in the absence of cytoplasmic streaming. However, is there an undiscovered mechanism present that mobilizes cytoplasm and its molecular contents, and delivers tRNAs to specific ribosomes at specific bacterial cytoplasmic locations? Mobilization of specific tRNA (and also mRNA transcripts and ribosomes) and cell division proteins to specific intracellular locations may suggest that instructions and/or mechanism(s) are needed. The alternative is that molecular crowding in the cytoplasm is sufficient for gentle contact between mRNA, ribosomes and tRNA. Or is it plausible that the bacterial cytoplasm (and its contents) are mobilized with the outcome being more gentle collisions between molecules than by a diffusion only mechanism? One hypothesis is that cytoplasmic and molecule mobilization and spatial organization are possibly driven by the photons in thermal infrared (IR) radiation and generation of exclusion zone (EZ) water in the cytoplasm.
\end{abstract}

\section{Introduction}

Molecular machines in living organisms are composed of proteins, lipids and nucleic acids in contained cellular cytoplasm and cells (Chari and Fischer, 2010). The individual required molecules are present at the same time in sufficient concentrations for macromolecular assembly to proceed. Macromolecules and their component molecules have often been described as being dependent on diffusion for their random walks or gentle collision interactions (Chari and Fischer, 2010). It is important to recognize that molecular motors also have a role in cytoplasmic mixing in eukaryotic organisms (Brangwynne et al., 2008). However, the mixing of bacterial cytoplasm is not well understood. The cytoplasm does not function as a watery milieu but as a structured gel with immense molecular crowding and some voids for diffusion of molecules (cytoplasmic void spaces that would not be continuous unless the cytoplasm was structured or organized as such). The mechanism(s) molecules and macromolecules use to mobilize and then locate specific, correct binding sites or cellular locations (sub-locations within the entire cytoplasm) within a confined

\footnotetext{
*Corresponding author: Email: jtrevors@uoguelph.ca
}

bacterial cytoplasm remain elusive (Kuthan, 2001). Large macromolecules such as ribosomes could become stationary at high crowding densities in the cytoplasm.

Crowding in the soft matter of the viscous or gel-like (Trevors and Pollack, 2005) bacterial cytoplasm describes the amount of water (or gel) in about a $\mu \mathrm{m}^{3}$ volume (or even less) and the size distribution of the macromolecules present in the spatially organized cytoplasm (Braun et. al., 2006). In the crowded cytoplasm of a bacterial cell such as Escherichia coli (Project CycerCell; http://redpoll.pharmany. ualberta.ca/CCDB/intron_new.html) there is the genome (sometimes replicating), RNA, ribosomes, inclusion bodies, and an estimated 120 million ions, 18 million small organic molecules and about 2.1 million proteins. These molecules and ions experience both specific and non-specific interactions (McGuffee and Elcock, 2010). The cytoplasmic composition comprises up to $40 \%$ of the cytoplasm volume and contains proteins, nucleic acids and other macromolecules where diffusion is one of the key mechanisms for molecular movement in the cytoplasm (Ando and Skolnick, 2010; Nenninger et al. 2010). Diffusion can be considered a random walk, nonreversible process that balances the concentration gradients (Weiss, 2008). Molecular crowding and diffusion are suitable for the bacterial cytoplasm as the molecules require little molecular space (molecules are not deformed but take on the correct conformations) and the cell dimensions and shapes are in the several microns in diameter order of magnitude. There is sufficient molecular space for DNA to unwind and replicate, plasmids and bacteriophages to be present, and for tens of thousands of ribosomes and all the required cell division proteins to assemble and disassemble at the correct cytoplasmic locations.

The situation is dynamic where molecules carry out their correct function (unless metabolic errors or toxicity occurs) while crowded into a microscopic cytoplasm where some interactions are random and other molecules are delivered to and/or localized at cytoplasmic locations. This confinement to the densely crowded bacterial cytoplasm means that diffusion is the major mechanism (Mika and Poolman, 2011) (but possibly not only mechanism) for movement and mixing where the higher the cytoplasmic crowding density of molecules, the lower the capacity for molecule mobility. However, the decreased mobility is offset by an increased capacity for self-association of molecules (Mika and Poolman, 2011) and possibly molecule localization. Evolution has got it correct because most bacterial cells have rapid generation times under optimal conditions, meaning that crowded molecular confinement and the correct time domains (Trevors, 2010a) are functioning for molecular reactions and cellular assembly and division. It is also recognized that sub-optimal and/ or stressed environmental conditions present challenges 
to the molecular machinery and structures of the bacterial cells.

Molecular crowding and confinement with some spatial localization of some molecules as well as a dynamic cytoplasm are processes that provide the correct amount of microscopic organization (lower entropy) than the external environment (Trevors, 2010b). Molecules like mRNA, ribosomes and cell division proteins must also be sufficiently stable for a period of time to allow the necessary regulated activities to proceed at the pace required for cell division. These activities are supported or made possible by the overall favorable thermodynamic metabolism of the energy yielding biochemical pathways and the organic genetic instructions in the DNA. Other considerations (Mika and Poolman, 2011) include how crowded is crowded during molecular confinement, what are the obstacles to diffusion, how does molecular weight and conformation influence movement, and how are some molecules delivered to specific bacterial cytoplasmic locations?

Molecules and macromolecules are moving, mobilized or delivered to specific locations at the correct times, often assuming that diffusion is the only operative mechanism (Mereghetti et al., 2011). However, inside a crowded or high molecule density bacterial cytoplasm, the presence of numerous other similar and different molecules will have profound effects on each other when the search for a specific molecular target is in progress via Brownian motion and diffusion. However, the total molecular interactions may not be the result of a diffusion random walk. Some molecules may be targeted to specific cytoplasmic locations. For example, nifH mRNA hybridizations in the non-symbiotic $\mathrm{N}_{2}$-fixing bacteria, Klebsiella oxytoca and Azotobacter vinelandii revealed that the signals were unevenly distributed in the cytoplasm. In K. oxytoca cells, the strongest signals were located at one or both cells poles (Pilhofer et al., 2009). It is plausible that nitrogen-fixation is somewhat localized in the cytoplasm to protect oxygen sensitive nitrogen-fixation and/or to have a readily available supply of nitrogen gas that enters the cells by diffusion.

In previous articles (Trevors, 2011b; Trevors and Pollack, 2011) hypothesized the possible role of thermal IR radiation and exclusion zone (EZ) water in the bacterial cytoplasm as factors that may influence the mobilization and location of molecules such as mRNA transcripts. In this article the hypothesis is further developed to discuss tRNA delivery to the ribosomes and cell division protein localization. If molecular diffusion (as opposed to cytoplasmic streaming in eukaryotes) is not the only method for mobilization of the bacterial cytoplasm and its contents, then other mechanisms will need to be hypothesized, researched and discovered.

In this article information and hypotheses are presented on how the bacterial cytoplasm and its molecular contents, for example, tRNAs delivered to ribosomes for gene expression to proceed. Bacterial transcription, translation and cell division proteins are examples that will be used in this article to explore molecule mobilization and delivery in the cytoplasm (see Table 1 for a summary of knowledge gaps and questions).

\section{Transcription and translation}

Bacterial transcripts can localize adjacent to the bacterial genome transcription sites. This is an interesting spatial organization as some transcripts are still required to be
Table 1. Some knowledge gaps on molecular movement/ mobilization, localization and interactions in the bacterial cytoplasm.

1. How do the tRNAs locate ribosomes?

2. Do tRNAs continue to locate ribosomes for a limited time after death of intact bacterial cells?

3. Is diffusion of tRNA in the cytoplasm the mechanism of contact with ribosomes?

4. Do tRNA-ribosome interactions result from random gentle collisions?

5 . Does thermal IR radiation influence molecule movement and produce exclusion zones (EZ) in the bacterial cytoplasm?

6 . Are the bending and stretching effects of IR radiation well documented and understood in living bacterial cells? 7. Is there a relationship between the amount of molecular crowding and the commencement of cell division in bacteria?

mobilized to contact the $30 \mathrm{~S}$ small ribosomal subunits, or the subunits must mobilize to contact the mRNA, or both the mRNA and subunits are mobile (Trevors, 2011b). The correct molecular contact or gentle collisions, and the recognition of correct molecular interactions in the cytoplasm are a necessity if cells are to function. Moreover, ribosomes, transcripts and tRNA would be moved about in the crowded cytoplasm with other molecules.

There are also ribosomes associated with the inner surface of the cytoplasmic membrane (CM) in Escherichia coli that translate specific membrane-bound proteins (Herskovitis and Bibi, 2000). An interesting question arises as to what is the mechanism if any, that mobilizes specific transcripts to specific ribosome locations adjacent to the inner surface of the cytoplasmic membrane. If diffusion in the cytoplasm is not the only mechanism, other plausible mechanisms will require research. However, because the cytoplasmic volume is in the order of about $1 \mu \mathrm{m}^{3}$ or even smaller, it is still plausible that diffusion is the only required mechanism in a crowded bacterial cytoplasm.

Another example of specific organization in the bacterial cytoplasm is RNA polymerase. Green fluorescent protein fusions to subunits of the RNA polymerase (RNAP) revealed some interesting observations in transcription and translation in Bacillus subtilis (Lewis et al., 2000). The RNAP was located mostly in the nucleoid region of cells while the ribosomes were almost exclusively located away from the nucleoid, at the septum location or midcell division site. mRNA would still need to be mobilie to contact the ribosomes. This demonstrates the cytoplasm is not homogenous, but spatially organized (Vendeville et al., 2010; Trevors, 2011a) and changing over time, which is required for mid-cell division.

Another interesting observation is that RNA movement in Escherichia coli cells is about $100 \%$ higher when the diffusion coefficient doubles, brought about by simply switching cells from a nutrient rich to nutrient poor minimal medium (Braun et al., 2006; Golding and Cox, 2006). This observation was explained by less molecular crowding (i.e., fewer ribosomes) in the nutrient poor medium. There are 
simply less molecules to impede molecule movement in the cytoplasm (Golding and Cox, 2006). Tagged mRNA in E. coli cells travelled the cell length several times during a 30-minute period. However, it was interesting that the movement was not continuous, but composed of rapid jumps and localized motion or discontinuous movements (Golding and Cox, 2006). Small, rapid movements may be attributed to inputs of thermal energy (Golding and Cox, 2006). This has profound significance as it is plausible that all molecules of different molecular weights and conformations in the cytoplasm are subjected to similar movements depending on the amount of thermal IR radiation the cytoplasm is receiving.

Experiments will be required where different species of living bacterial cells are exposed to varying amounts of IR radiation over different times (under different environmental conditions and controls) and the movement of tagged molecules observed/recorded. It would be valuable knowledge to understand if the effects of the thermal radiation varies between diverse bacterial species, doses, wavelengths and exposure times to IR radiation, and the IR radiation emitted by both living and dead cells as controls. Diffusion and gentle contacts or interactions between molecules influenced by thermal IR radiation may contribute to molecule movement in the bacterial cytoplasm as there is presently no known mechanism of directed cytoplasm movement in bacteria. This will be discussed in more detail in this article.

In bacterial transcription and translation, the correct molecules locate each other in the bacterial cytoplasm for gene expression to proceed. This permits rapid generation times under optimal environmental conditions and global gene responses under often rapidly changing conditions. In addition, mRNA must remain stable and contact the small subunits (30S) of the bacterial ribosome, responsible for mRNA decoding (Williamson, 2008). The small subunit contains 21 ribosomal proteins and the $16 \mathrm{~S}$ ribosomal RNA. The complete functional ribosome assembly requires the additional $50 S$ subunit, together producing the $70 S$ assembled functional bacterial ribosome.

Translation of the mRNA to the corresponding protein then proceeds using the universal genetic code of 61 codons for 20 amino acids and three stops signal codons (Agris et al., 2007). The code is also degenerate as most amino acids are encoded by more than one codon. Nine amino acids are encoded by two codons per each amino acid, five amino acids are encoded by four codons per each amino acid, and there are three amino acids that have six codons. Only one amino acid has three codons, while two amino acids have unique codons (Agris et al., 2007). Bacterial translation requires the correct individual transfer RNAs (40 in total tRNAs) to be mobile and deliver the specific amino acids to the correct or specific ribosomes.

The ribosome has three specific molecular locations for the tRNA substrate molecules, each residing on both subunits (Wekselman et. al., 2008). It is the A-site location that hosts the aminoacyl-tRNA (aa-tRNA). The decoding location is on the small 30 S subunit where the mRNA codon and the tRNA anticodon loops are attached. The PTC (peptidyl transferase center) is on the large 50S subunit (Wekselman et al., 2008). As stated in a recent excellent article by Wekselman et. al (2008), the tRNAs bring the amino acids to the ribosomes. However, the delivery mechanism for the tRNAs has not been elucidated for bacteria, but generally has been assumed to be diffusion in the crowded cytoplasm.

The question is posed- how do the tRNAs mobilize or deliver the correct amino acids to the ribosomes in the spatially, organized, molecularly, crowded, bacterial cytoplasm? Secondly, are the ribosomes, mRNA transcripts, tRNA and all bacterial cytoplasmic molecules assisted in their diffusion movement by some mechanism such as a thermal input?

It has been generally assumed that diffusion, not cytoplasmic streaming, in the bacterial cytoplasm is the mechanism of molecule movement. The assumption being that the correct tRNAs are delivered to the correct fully assembled ribosome, and this was sufficient for rapid gene expression (and therefore rapid generation times in bacteria) depending on the environmental conditions present for the bacteria. Moreover, the diffusion mechanism is over short cytoplasmic distances ( $\mu \mathrm{m}$ range) with short time scales in a crowded bacterial cytoplasm. Both the short cytoplasmic distances, small microscopic cell volumes and corresponding generation times mean that the tRNA, ribosome and mRNA transcripts remain stable for the necessary lengths of time for completion of gene expression.

\section{Cell division proteins}

The previous discussion raised questions about mechanisms that may make molecules move and be correctly delivered to other molecules and/or located at specific cytoplasmic locations in bacteria. A key event (or mechanism) in the origin and subsequent evolution of bacterial life is controlled cell division (Trevors, 2004). Bacterial cell division in $E$. coli involves a mid-cell divisome of 10 or more specific proteins. Cell division is an excellent example to examine for mobilization, localization and disassembly of proteins (Trevors, 2004). Bramhill and Thompson (1994) reported that tubules of the FtsZ cell division protein forms a cytoskeleton structure (i.e., organization in the cytoplasm) involved in bacterial septum formation. The FtsZ protein locates at the mid-cell location just prior to bacterial cell division. The Z-ring completely disassembles which relocates to the remainder of the cytoplasm after division (Bramhill and Thompson 1994). Rod-shaped bacterial cells such as Escherichia coli and Bacillus subtilis form a septum in the middle of the cell, $90^{\circ}$ to the cell length.

In Bacillus subtilus, a thick septum is formed but the outer cell envelope does not constrict like $E$. coli to produce two offspring cells (Margolin 2000). Instead, B. subtilis (spore-forming bacterium) has two modes of cell division (Graumann and Losick, 2001). The vegetative cells divide by binary fission with a septum at the mid-cell location. However, during sporulation the cells undergo asymmetric division. The septum becomes located near one end of the vegetative cell. This outcome is a smaller forespore and the larger original cell (Graumann and Losick, 2001). This process is controlled by an unknown gene(s) under the regulation of the SpoOA (sporulation response regulator) (Graumann and Losick, 2001) that makes the FtsZ locate at the poles of the cell, not the mid-cell. Moreover, a complete chromosome is not partitioned to the forespore. About $1 / 3$ of the chromosome is partitioned with the remainder $(2 / 3)$ pumped across the septum from the mother cell. 
This mechanism of cell division illustrates the complexity of division and how specific locations in the cytoplasm become spatially organized with the required proteins at the correct time. Regulated cell polarity and protein recruitment (with possibly still to be better understood mechanisms) at specific locations requires additional research.

\section{Is IR radiation a plausible driving mechanism for bacterial cytoplasm mobilization?}

Thermal fluctuations have a fundamental role in both living and non-living matter as it provides a mechanism for diffusive motion. It was previously hypothesized that thermal $\mathrm{I} R$ radiation may have a plausible role in mobilizing bacterial cytoplasm and its contents (Trevors and Pollack, 2011). It was hypothesized this occurs by IR (infrared) radiation that mobilizes the cytoplasm and its contents, and also produces a negatively charged exclusion zone (EZ) next to surfaces such as the cytoplasmic membrane (Trevors and Pollack, 2011). The IR radiation will also bend and stretch bonds in molecules if photons are absorbed by the molecules at specific wavelengths (Trevors and Pollack, 2011).

A negatively charged exclusion zone generated next to the inner hydrophilic surface of the cytoplasmic membrane (CM) could possibly exclude the negatively charged DNA (large polyanion) and negatively-charged RNA transcripts. However, some transcripts and ribosomes are known to be located next to the membrane. It should also be recognized that a negatively charged exclusion zone could be influenced by the presence of a large number of positive potassium ions in the bacterial cytoplasm that could neutralize some negative charges. An understanding of the structuring of the cytoplasm clearly requires much more research.

If a cytoplasmic mobilization mechanism is occurring in the bacteria, is there a plausible hypothesis as to what this mechanism is? One hypothesis is thermal energy in the form of infrared radiation (IR, 10,000 to $10 \mathrm{~cm}^{-1}$; Burgula et al., 2007) that exerts an effect on the bacterial cytoplasm (and cytoplasm in all organisms) producing an exclusion zone (EZ), and also moves or mobilizes molecules within the cytoplasm as well as bending and stretching specific bonds. The exclusion zone is where the water is negatively charged, while bulk water beyond the exclusion zone has a positive charge. The charge differential was estimated to be between 100-200 mV (Pollack et al., 2011; Trevors and Pollack 2011). Pollack et al., (2011) hypothesized that electromagnetic energy (including UV, visible and infrared radiation) especially effective at the IR wavelength of 3.1 $\mu \mathrm{m}$ (Pollack et. al., 2011) can cause exclusion zones in water. The more ordered negative exclusion zone expands in the presence of incident radiant energy (Chai et al., 2009). ). In addition, osmosis of water into bacterial cells that then becomes part of the cell/cytoplasm, would be subjected to cytoplasmic exclusion zone formation if such a mechanism was operating. It is not understood if the slow inward diffusion of water into the cytoplasm causes any gentle molecular mixing, but this may also be plausible.

What remains to be discovered is if such a process occurs in the cytoplasm of bacterial cells as the radiant energy appears to split the water into negative EZ water and a positive zone. Even though the IR photons are low energy and long wavelengths, they may simply assist or augment the normal disassociation of water under physiological life conditions. The exact mechanism is not understood, but the IR photons do bend and stretch bonds that absorb at the respective wavelengths. It is plausible that the IR photon energy absorbed by water was a component in the origin of life, subsequent evolution and is still a functional mechanism in the quantum biology and molecular biology of present day living organisms.

One can ask why IR radiation would have such a profound effect on molecules in living organisms? $\mathrm{IR}$ radiation is everywhere and cells emit IR radiation signatures. It is recognized however, that IR radiation would interact with all molecules that could absorb and emit the corresponding IR wavelengths. Bacterial cells are not equally exposed to IR radiation from all sources. An example is bacterial cells in the Earth's subsurface would not be exposed similar to cells on the surface. Also, cells produce their own radiant energy as well as being exposed to radiant energy from geothermal sources, cosmic background IR and the sun. Thermal imaging cameras/ devices can provide a temperature signature of dwellings, a human body or a colony of bacterial cells. At temperatures above absolute zero, atoms are in continuous motion. If the frequency of the atom vibration is equal to the frequency of the IR source, the molecule absorbs the radiation. When $\mathrm{IR}$ radiation is absorbed, the associated photon energy is converted into molecular vibrations that stretch and bend bonds in the cytoplasm (of all living organisms). For example, at $540 \mathrm{~cm}^{-1}$ the assignments are C-O; P-O-C such as in phospholipids and RNA. At $3000 \mathrm{~cm}^{-1}$, the possible assignments in Bacillus subtilis cells are are $\mathrm{NH}_{2}$ stretching in adenine, cytosine, quinine and $\mathrm{H}$-bonded $\mathrm{OH}$ groups (Filip et al., 2004).

The question was raised concerning the possibility that IR radiation that bends and stretches bonds in living organisms may also assist in molecule movement in the cytoplasm. More gentle collisions may mean more opportunities for the correct molecules to gently collide with each other in the bacterial cytoplasm if the molecular crowding is not so restrictive to be an obstacle to molecule movement. It is also recognized there are fewer molecular collisions in a crowded cytoplasm as the physical space is crowded and movement is decreased. Figure 1 summarizes information on the crowded, organized, cellular processes in the bacterial cell cycle (period from one cell division to the next) and the plausible effects of IR thermal radiation and possible exclusion zones (EZ), that both require additional research, in living cells.

\section{Summary and outlook perspective}

Soft matter bacterial cells can be viewed from the perspective of a total array of genes in the genome (with the capacity to be altered by mutations and gene transfer events and ) and the genes expressed in response to the environmental conditions present and the multitude of molecular recognition events occurring at the time the genes are being expressed. The bacterial cell is soft matter with the capacity to recognize and execute all the molecular interactions required for cell growth and division (and others not strictly required for growth and division). This can be viewed as a regulated array of molecular interactions that are altered depending on the environmental conditions, genes expressed (e.g., global gene expression analysis) and the bacterial species/strains.

The once traditional view that bacterial cells are 


\section{Higher entropy often changing external environment}

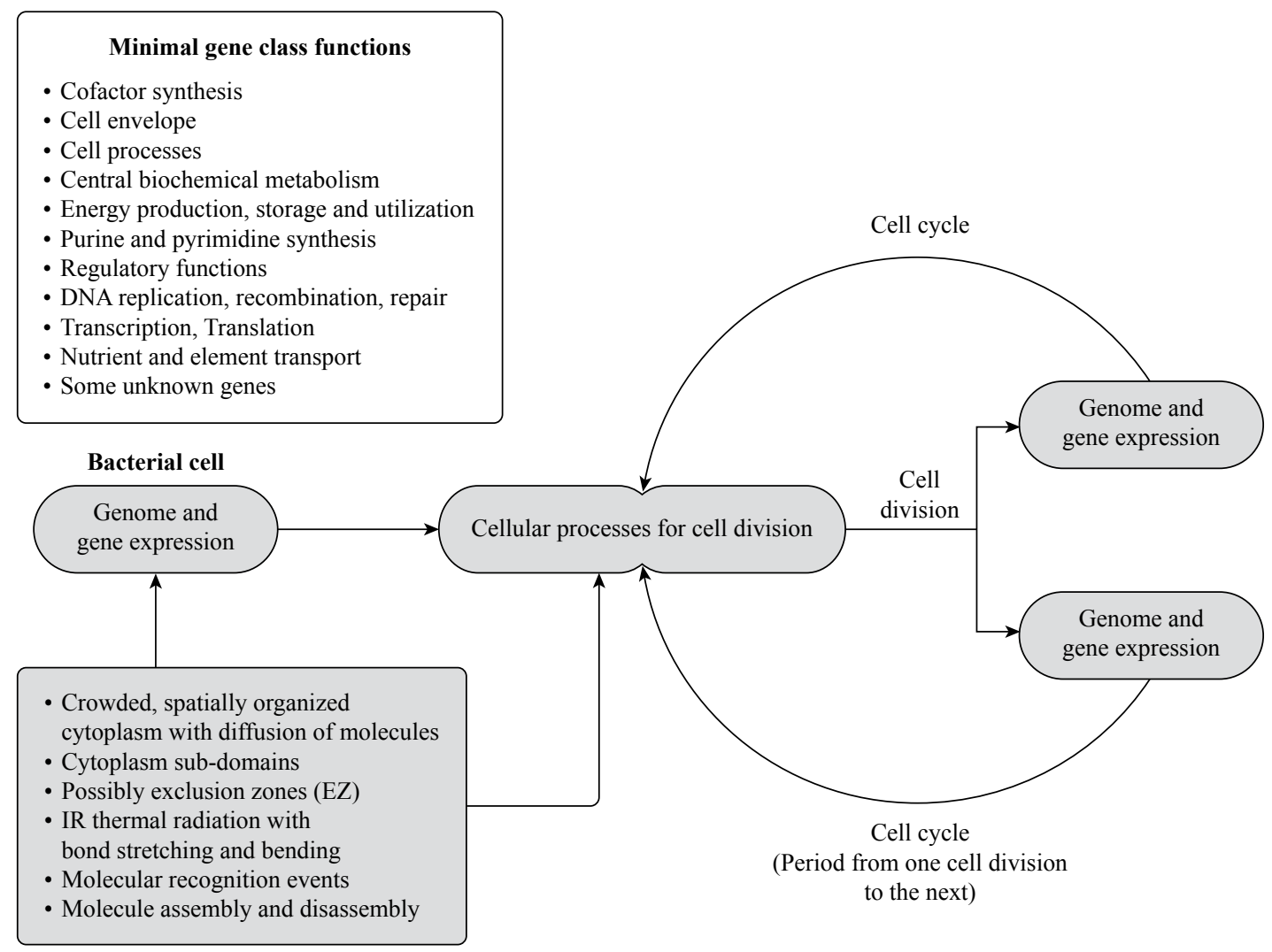

Figure 1. Hypothesized presence of IR radiation and its possible effects such as generating exclusion zone (EZ) water, known bond bending and stretching, in addition to the known cellular processes for cell growth and division, in molecularly crowded, spatially, organized bacterial cells.

enclosed sacs of macromolecules where diffusion governs all molecular interactions is being replaced by the knowledge of a spatially organized and crowded bacterial cytoplasm. Diffusion would define the upper limits of bacterial biochemistry if this was the only mechanism of molecule movement. The amount of molecular crowding determined by the evolutionary history of bacterial cells has selected for cells with the correct morphology, dimensions, and number of molecules, ions, cytoplasmic volume and respective, dynamic, molecular crowding during the cell cycle (period from one cell division to the next).

The bacterial ribosome (70S) with two subunits (30 and $50 S$ ) are the protein assembly units of the cells. However, for translation to proceed, the mRNA must be present at the assembled ribosome and then the correct tRNAs must deliver the specific amino acids in the correct order. The entire gene expression process requires movement and delivery of macromolecules in the bacterial cytoplasm within a time range where all the required molecules are present at non-limiting concentrations. However, does the combination of molecular crowding and diffusion of molecules in the cytoplasm explain how transcripts mobilize to contact ribosomes and how tRNAs deliver the correct amino acids to fully assembled 705 bacterial ribosomes? If the bacterial cytoplasm does not stream such as in eukaryotes, is it mobilized via another mechanism that assists in gentle but required molecular collisions between macromolecules? Some transcripts and ribosomes can localize at specific locations in the cytoplasm. The hypothesized role of IR radiation generating exclusion zone chemistry in the cytoplasm and increasing the frequency of molecular collisions requires research to bring forth supporting or nonsupporting observations.

Science is in need of transformative discoveries that are correct in understanding energy, matter, light, organic genetic instructions and the organization of living soft matter. It may be that the knowledge gaps on how the entire EM spectrum and in particular IR radiation, interacts with living organisms, are more profound than currently known. This places biophysics researchers and other science disciplines in an excellent position to better understand how inanimate matter became living and the role of thermal radiation in the origin of life and its subsequent evolution. Perhaps underlying quantum knowledge (Trevors, 2011c; 
Trevors and Masson, 2011) will also assist in allowing our understanding of complex living organisms to be simplified by a single underlying principle that unifies our understanding of life, such as the EM spectrum and matter interactions.

Currently, our most profound and correct view of life uses the cell as the most fundamental unit of life (cell theory) and organic genetic instructions and the universal genetic code. Any new fundamental underlying understanding (i.e., universal foundation for the origin of life and subsequent evolution) of life will require more understanding of the foundations of light, energy, matter, the laws of thermodynamics and the universal nature of what is living matter, and how it is challenged by increasing entropy.

It is rational to closer examine the interactions between IR radiation and living matter. Given that photons act both as particles and organized waves, are virtually massless and interact with matter and non-living matter, it is logical that science needs to better understand these interactions. Nature also has periodic cycles such as day and night (temperature cycles and light/dark cycles) that possibly had a significant influence on the origin of life and its subsequent evolution. Decreased inputs of IR thermal radiation during the night may also have profound effects on the origin and subsequent evolution of life and possibly an undiscovered, but underlying unity principle in nature related to EM radiation and the quantum basis of matter, and as an extension, life. Knowledge on the intracellular movement, delivery and localization of molecules would profoundly advance the understanding of molecular interactions in bacterial cells. This in turn would allow a better understanding of cell assembly, cell division in bacterial species, and may also provide additional clues to the origin of bacterial life. This may be achieved by the correct understanding of molecular interactions (e.g., possibly a biosystems approach) in bacteria.

\section{Acknowledgements}

Research by J.T.T. is supported by the Discovery Program of NSERC (Canada).

\section{References}

Agris, P. F., F. A. P. Vendeix and W. D. Graham. 2007. tRNA's wobble decoding of the genome: 40 years of modification. J. Mol. Biol. 366;1-13.

Ando, T. and J. Skolnick. 2010. Crowding and hydrodynamic interactions likely dominate in vivo macromolecular motion. PNAS. 10:18457-184562.

Brangwynne, C. P., G. H. Koenderink, F. C. MacKintosh and D. A. Weitz. 2008. Cytoplasmic diffusion: molecular motors mix it up. J. Cell Biol. 183(4)583-587.

Bramhill, D. and C. M. Thomson. 1994. GTP-dependent polymerization of Escherichia coli FtsZ protein to form tubules. Proc. Natl. Acad. Sci. USA. 91:5813-5817.

Braun, F. N., W. P. Krekelberg and T. M. Truskett. 2006. Volatile diffusional character of cytoplasm. J Phys. Chem. B Letts. 110:25606-25607.

Burgula, Y., D. Khali, S. Kim, S.S. Krishman, M. A. Cousin, J. P. Gore, B. L. Reuhs and L. J. Mauer. 2007. Review of mid-infrared spectroscopy applications for bacterial detection. J. Rapid Meths. Automat. Microbiol. 15: 146175 .
Chai, B., H. Yoo and G. H. Pollack. 2009. Effect of radiant energy on near-surface water. J. Phys. Chem. B. 113: 13953-13958.

Chari, A. and U. Fischer. 2010. Cellular strategies for the assembly of molecular machines. Trends Biochem. Sci. 35: 676-683.

Filip, Z., S. Herrman and J. Kubat. 2004. FT-IR spectroscopic characteristics of differently cultivated Bacillus subtilis. Microbiol. Res. 159:257-262.

Golding, I. and E. C. Cox. 2006. Physical nature of bacterial cytoplasm. Phys. Rev. Letts. 96: 098102.

Graumann, P. L. and R. Losick. 2001. Couplind of asymmetric division to polar placement of replication origin regions in Bacillus subtilis. J. Bacteriol. 183:4052-4060.

Herskovitis, A.A. and E. Bibi. 2000. Association of Escherichia coli ribosomes with the inner membrane requires the signal recognition particle receptor but is independent of the signal recognition particle. PNAS 97:4621-4626.

Kuthan, H. 2001. Self-organization and orderly processes by individual protein complexes in the bacterial cell. Prog. Biophys. Mol. Biol. 75:1-17.

Lewis, P. J., S. D. Thaker and J. Errington. 2000. Compartmentalization of transcription and translation in Bacillus subtilus. EMBO J. 19:710-718.

Margolin, W. 2000. Themes and variations in prokaryotic cell division. FEMS Microbiol. Revs. 24:531-548.

McGuffee, S. R. and A. H. Elcock. 2010. Diffusion, crowding and protein stability in a dynamic molecular model of the bacterial cytoplasm. PLoS Computational Biol. 6(3) e1000694.

Mereghetti, P., D. Kokh, K. A. McCammon and R. C. Wade. 2011. BMC Biophysics. 4:2 2046-1682/4/2

Mika, J. T. and B. Poolman. 2011. Macromolecule diffusion and confinement in prokaryotic cells. Curr. Opin. Biotechnol. 22: 117-126.

Nenninger, A., G. Mastroiannia nd C. W. Mullineaux. 2010. Size dependence of protein diffusion in the cytoplasm of Escherichia coli. J. Bacteriol. 192: 4535-4540.

Pilhofer, M., M. Pavlekovic, N.M. Lee, W. Ludwig and K.$\mathrm{H}$. Schleifer. 2009. Fluorescence in situ hybridization for intracellular localization of nifH mRNA. Sys. Appl. Microbiol. 32: 186-192.

Pollack, G. H., X. Figueroa and Q. Zhang. 2011. The minimal cells and life's origin: role of water and aqueous interfaces. In P. L. Luisi and P. Stano (eds.) The Minimal Cell: The Biophysics of Cell Compartment and the Origin of Cell Functionality, Springer, pp. 105-121.

Trevors, J. T. 2004. Evolution of cell division in bacteria. Theory in Biosciences. 123/1:3-15.

Trevors, J. T. 2010a. Perspective: time scales in scientific research: microbial cellular and molecular research. J. Microbiol. Meths. 82:102-107.

Trevors, J. T. 2010b. Suitable microscopic entropy for the origin of microbial life: microbiological methods are challenges. J. Microbiol. Meths. 83:341-344.

Trevors, J. T. 2011a. The composition and organization of cytoplasm in prebiotic cells. Int. J. Mol. Sci. 12:1650-1659.

Trevors, J. T. 2011b. Bacterial transcripts: how do they mobilize in the spatially crowded cytoplasm to contact the 30 S ribosomal small subunit? (submitted to Prog. Biophys. Mol. Biol.) 
Trevors, J. T. 2011c. Origin of microbial life: nano- and molecular events, thermodynamics/entropy, quantum mechanisms and genetic instructions. J. Microbiol. Meths.84: 492-495.

Trevors, J. T. and L. Masson. 2011. Quantum microbiology. Curr. Issues Mol. Biol. 13: 43-50.

Trevors, J.T. and G. H. Pollack. 2005. Hypothesis: the origin of life in a hydrogel environment. Prog. Biophys. Mol. Biol. 89:1-8.

Trevors, J. T. and G. H. Pollack. 2011. Origin of life hypothesis: a gel cytoplasm lacking a bilayer membrane, with infrared radiation producing exclusion zone (EZ) water, hydrogen as an energy source and thermosynthesis for bioenergetics. Biochemie (in press).
Vendeville, A., D. Lariviere and E. Fourmentin, 2010. An inventory of the bacterial macromolecular components and their spatial organization. FEMS Microbiol. Rev. xx:120. DOI: 10.1111/j.1574-6976.2010.00254.x

Weiss, M. 2008. Probing the interior of living cells with fluorescence correlation spectroscopy. Ann. N. Y. Acad. Sci. 1130:21-27.

Wekselman, I., C. Davidovich, I. Agmon, E. Zimmerman, H. Rozenberg, A. Bashan, R. Berisio and A. Yonath. 2008. Ribosome's mode of function: myths, facts and recent results. J. Pep. Sci. DOI 10.1002/psc.1077.

Williamson, J.R. 2008. Biophysical studies of bacterial ribosome assembly. Curr. Opin. Struct. Biol. 18: 299-304. 


\section{Further Reading}

Caister Academic Press is a leading academic publisher of advanced texts in microbiology, molecular biology and medical research. Full details of all our publications at caister.com

- MALDI-TOF Mass Spectrometry in Microbiology Edited by: M Kostrzewa, S Schubert (2016) www.caister.com/malditof

- Aspergillus and Penicillium in the Post-genomic Era Edited by: RP Vries, IB Gelber, MR Andersen (2016) www.caister.com/aspergillus2

- The Bacteriocins: Current Knowledge and Future Prospects Edited by: RL Dorit, SM Roy, MA Riley (2016)

www.caister.com/bacteriocins

- Omics in Plant Disease Resistance Edited by: V Bhadauria (2016) www.caister.com/opd

- Acidophiles: Life in Extremely Acidic Environments Edited by: R Quatrini, DB Johnson (2016) www.caister.com/acidophiles

- Climate Change and Microbial Ecology: Current Research and Future Trend

Edited by: J Marxsen (2016)

www.caister.com/climate

- Biofilms in Bioremediation: Current Research and Emerging Technologies

Edited by: G Lear (2016)

www.caister.com/biorem

- Microalgae: Current Research and Applications Edited by: MN Tsaloglou (2016) www.caister.com/microalgae

- Gas Plasma Sterilization in Microbiology: Theory, Applications, Pitfalls and New Perspectives Edited by: H Shintani, A Sakudo (2016) www.caister.com/gasplasma

- Virus Evolution: Current Research and Future Directions Edited by: SC Weaver, M Denison, M Roossinck, et al. (2016) www.caister.com/virusevol

- Arboviruses: Molecular Biology, Evolution and Control Edited by: N Vasilakis, DJ Gubler (2016) www.caister.com/arbo

- Shigella: Molecular and Cellular Biology Edited by: WD Picking, WL Picking (2016) www.caister.com/shigella

-Aquatic Biofilms: Ecology, Water Quality and Wastewater Treatment

Edited by: AM Romaní, H Guasch, MD Balaguer (2016)

www.caister.com/aquaticbiofilms

- Alphaviruses: Current Biology

Edited by: S Mahalingam, L Herrero, B Herring (2016)

www.caister.com/alpha

- Thermophilic Microorganisms

Edited by: F Li (2015)

www.caister.com/thermophile
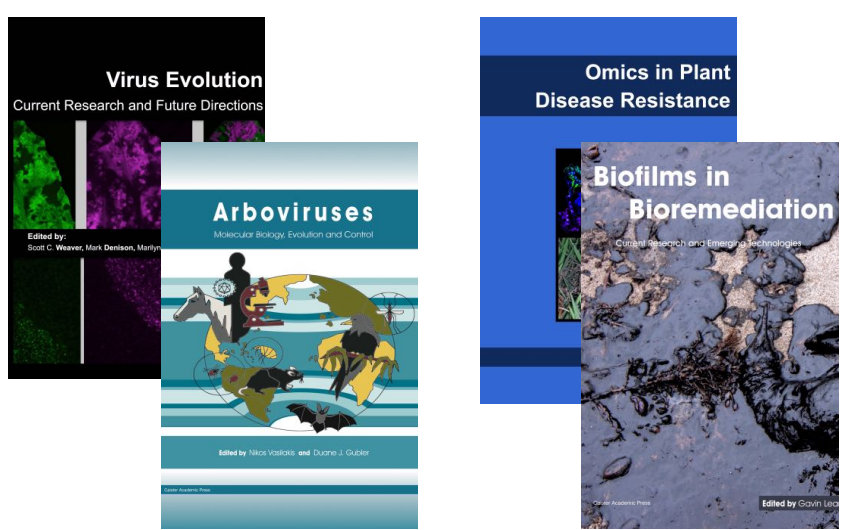
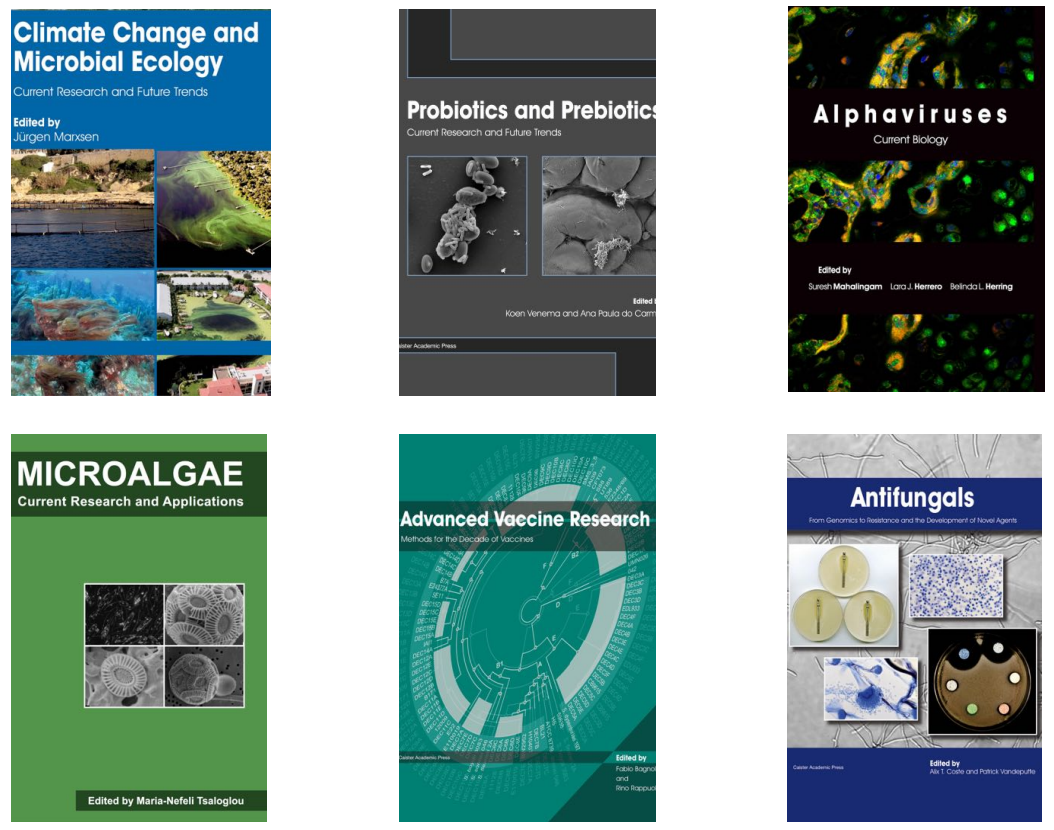

- Flow Cytometry in Microbiology: Technology and Applications Edited by: MG Wilkinson (2015) www.caister.com/flow

- Probiotics and Prebiotics: Current Research and Future Trends Edited by: K Venema, AP Carmo (2015) www.caister.com/probiotics

- Epigenetics: Current Research and Emerging Trends Edited by: BP Chadwick (2015) www.caister.com/epigenetics2015

- Corynebacterium glutamicum: From Systems Biology to Biotechnological Applications

Edited by: A Burkovski (2015)

www.caister.com/cory2

- Advanced Vaccine Research Methods for the Decade of Vaccines

Edited by: F Bagnoli, R Rappuoli (2015)

www.caister.com/vaccines

- Antifungals: From Genomics to Resistance and the Development of Novel Agents

Edited by: AT Coste, P Vandeputte (2015)

www.caister.com/antifungals

- Bacteria-Plant Interactions: Advanced Research and Future Trends Edited by: J Murillo, BA Vinatzer, RW Jackson, et al. (2015) www.caister.com/bacteria-plant

\section{- Aeromonas}

Edited by: J Graf (2015)

www.caister.com/aeromonas

- Antibiotics: Current Innovations and Future Trends

Edited by: S Sánchez, AL Demain (2015)

www.caister.com/antibiotics

- Leishmania: Current Biology and Contro Edited by: S Adak, R Datta (2015) www.caister.com/leish2

- Acanthamoeba: Biology and Pathogenesis (2nd edition) Author: NA Khan (2015)

www.caister.com/acanthamoeba2

- Microarrays: Current Technology, Innovations and Applications Edited by: Z He (2014)

www.caister.com/microarrays2

- Metagenomics of the Microbial Nitrogen Cycle: Theory, Methods and Applications

Edited by: D Marco (2014)

www.caister.com/n2 